\title{
THE IDENTITY OF THE CATTLE HERDSMAN \\ A STUdy in the SCENes OF ANCIENT Egyptian Private TombS
}

By

\author{
Naglaa Fathy Shehab \\ Assistant Professor, al Alson Higher Institute for Tourism and Hotels, Egypt
}

[AR]

هُوية راعى الأبقار: دراسة فى مناظر المقابر المصهرية القديمة الخاصهة

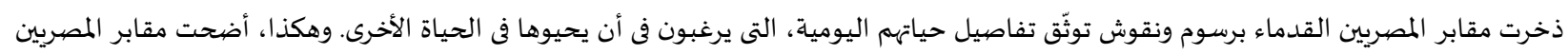

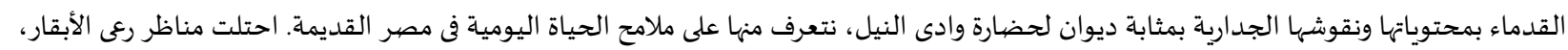

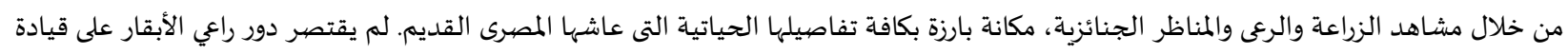

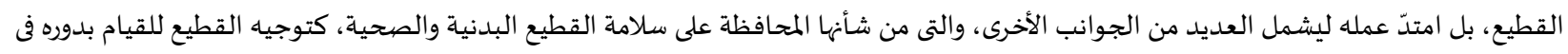
أعمال الزراعة أوالرعى والامتثال، أما صاحب المقبرة وكذلك المشاركة في المناظر الجنائزية. تهدف هذه الورقة البحثية إلى معرفة هوية راعى البقر، والذى اتسم دائما بالنحافة والجسم الهزيل بحكم مهنته وقلة قوته. شارك فى هذه المهنة جميع الفئات العمرية من الصبيان والشباب وكبار السن، وتنوعت درجاتهم

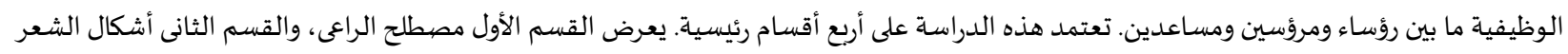

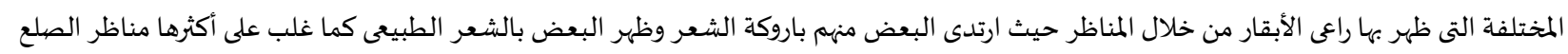
بأنواعه المختلفة، فى القسم الثالث، نستعرض زي الرعاة، والذي اختلف حسب ألقابهم الاجتماعية، فظهرت الطبقة الدنيا منهم عراة، وظهرت الطبقة العامة بالنقبة القصيرة، أما الرؤساء منهم فظهروا بنقبة ذات نتؤات أمامية. فى القسم الرابع، نتعرف على أدوات الرعاة المستخدمة في قيادة القطيع مثل العصياة

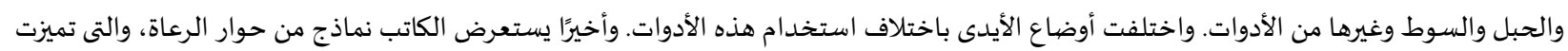
دائمًا بالبساطة والواقعية، وتكشف الكثير عن سماتهم الشخصية والعملية من خلال واقع وظيفتهم.

[EN] The tomb wall scenes give art historians a glimpse into ancient Egyptian daily life, allowing them to piece together a vision of their civilization. The depictions of animals in the scenes of daily life are commonly found in ancient Egyptian tombs. The image of the cattle herdsman has been regarded as one of the «daily life» scenes. The great collection of iconography portraying herdsmen attests to the crucial significance they played in Egyptian visual culture. The present paper is concerned with the identity of the cattle herdsman. It is divided into four main sections. The first section defines herdsman and reviews the activities in which he participated. The second section presents the different hairstyles in which the herdsmen appeared throughout the scenes. The third section reviews the herdsman's costume. The fourth section is devoted to the job of the herdsmen by showing the different positions of using the grazing tools. Finally, the author gives some examples of captions for herdsman scenes to explore their conversational style, work-related characteristics, knowledge of cows, and innate instincts.

KEYWORDS: Herdsman, cattle-drover, herd, animal husbandry, cattle, stick, rope 


\section{INTRODUCTION}

Throughout ancient Egyptian history, elite members of society carved and painted detailed depictions of the living and divine worlds on the walls of their tombs. Elite tombs, conceived as a «house for eternity,» were tasked with a variety of important functions ${ }^{1}$. In addition to providing security for the body, tombs served as a ceremonial complex to ensure the dead's regeneration and eternal well-being, a space where the deceased's identity could be projected into the afterlife and remembered by the living, and a place for protecting the body. Tombs were built, and their language and art were created to support these functions and ease the transition from life to death. The owners displayed themselves as they wished through a carefully chosen collection of culturally accepted scenes and inscriptions, with tomb design, text, and images organized to match these tasks and ease the passage from life to the afterlife ${ }^{2}$.

The portrayal of the natural environment was a crucial element of elite tomb iconography, with a wide range of scene types, recording animals attesting to their central role in ancient civilization. Animals were present in practically every element of life, and their frequent occurrence in the culture's visual records provided a constant source of evidence for those studying the Egyptian people and environment ${ }^{3}$. Animal motifs were frequently used as a source of information about Egyptian people's lives, ideas, and religious beliefs ${ }^{4}$. Thus, the depictions of animals in scenes of daily life are commonly found in ancient Egyptian tombs ${ }^{5}$.

Not only did agricultural output, closely related to these animals, grow throughout time, but so did the quantity and size of herds, which, like the soil, were owned by large estate owners and tended by expert herdsmen. These herdsmen were supervised and controlled by their own managers and assistants like «bucket carriers» and «fodder men». Cattle, geese, sheep, asses, dogs, oryx, horses, other poultry, and even pigs were all used for specific purposes ${ }^{6}$.

\section{Methodology}

This paper attempts to provide an analytical-descriptive examination of the many modalities of representation related to herdsmen figures in ancient Egyptian private tombs, i.e., the term, hairstyle, costume, job, and tools used in their daily work. Moreover, it reviews some of the dialogues between herdsmen. Most of these examples

\footnotetext{
1 ASSMANN 2002: 66; WOODS 2017: 77.

2 VERMA 2014: 37, 112; HARTWIG 2004: 1-5; DODSON \& IKRAM 2008: 77-79.

${ }^{3}$ EVANS 2010: 1.

${ }^{4}$ IKRAM 1995: 32, 2005: 72 - 105; HOULIHAN 1996: 212; GERMOND \& LIVET 2001:7; BAILLEUL-LeSUER 2012: 27; HARTLEY et Al. 2017:100-9; PORCIER et AL. 2019: 243-250.

${ }^{5}$ EVANS 2000: 73; GERMOND \& LIVET 2001:7.

${ }^{6}$ BREWER 2001: 436; EVANS 2010:2.
} 
were from the Old and New Kingdoms, with the earliest relief coming from the $4^{\text {th }}$ Dynasty and the latest belonging to the $20^{\text {th }}$ Dynasty.

\section{The term of herdsman}

In ancient Egyptian texts, the terms «herdsman, shepherd, and drover» were expressed in more than one word, as follows:

○n with different determinatives $(9,10)$ was traditionally translated as «herdsman»7. Some dictionaries ${ }^{8}$ mentioned it with: 0 in «herdsman» or «cow-keeper». Furthermore, the term $i h w$ was identified as «herdsman of the cattle».

This term was mentioned through one of the texts of the tomb of Ty- Saqqara $5^{\text {th }}$ Dynasty, as follows: In the left (west) part of the north wall, register 2, right-hand part.

A herd of nine cattle was depicted crossing a ford. A warning from someone in the boat was heard above the cattle as follows ${ }^{9}$ :

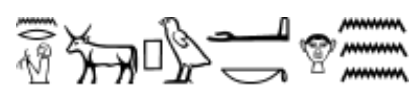

nr pw':k hr mw

«Herdsman! your hand is on the water».

The second scene from the tomb of Userhat- TT56, North wall: To the right, the three sub-registers (devoted to the temple of Amon's cattle), are the scribes who record everything. The two at the top sit cross-legged and write their report on the papyrus sheet in front of them, which includes the number, sex, and age of the animals. In the text, there is a comment about the scene as follows ${ }^{10}$ :

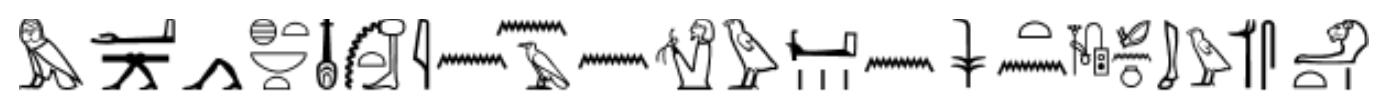

ms ht nbt nfr(t) w'bt in n3n nrw $n$ nsw sš idnw whm.w Wsr-ḩ3t

"Let's return all the good and pure things of the herdsmen to the royal scribe Userhat, the reporter's representative.» ${ }^{11}$

The term

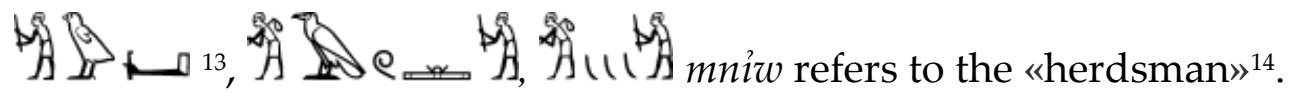

\footnotetext{
${ }^{7}$ ERMAN \& GRAPOW (EDS.): Wb.2, 1.279.

${ }^{8}$ ERMAN \& GRAPOW (EDS.): Wb.2, 2-3, 4279; FAULKNER 1962:135.

${ }^{9}$ WILD 1953: PL.XCIII-A.

${ }^{10}$ PORTER \& MOSS: PM, 111-113; BEINLICH-SEEBER \& SHEDID 1987 :TAF.15

${ }^{11}$ HELCK: Urk IV: 1477; WRESZINSKI I 1923: 187.

12 ERMAN \& GRAPOW (EDS.): Wb.2, 11-13, 75.

${ }^{13}$ FAULKNER 1962: 108; GARDINER 1957:447.

${ }^{14}$ LESKO 1982: 218
} 
This term was mentioned in one of the texts of the tomb of Nakhtamon (TT341), the «Overseer of the altar». East wall- bottom register of the south wing: At the far side of the animals is a herdsman, whose hair was shaven in a tonsure style. He makes the beasts walk forwards with the help of a stick. He is accompanied by the text ${ }^{15}$ :

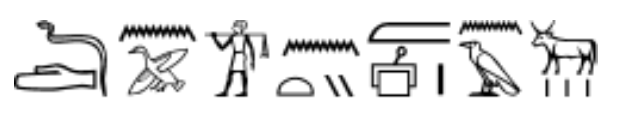

dd $n$ p 3 mniw nty m sz nziwzw

«Spoken by the herdsman who is held behind the cattle».

Lesko mentioned that the term «herdsmen, guard, guardian, and cow-herd». He added that s3w and mniw ${ }^{17}$ were translated as «herdsmen».

Furthermore, some other terms were less used to express the word «herdsman, shepherd, or drover, such as:

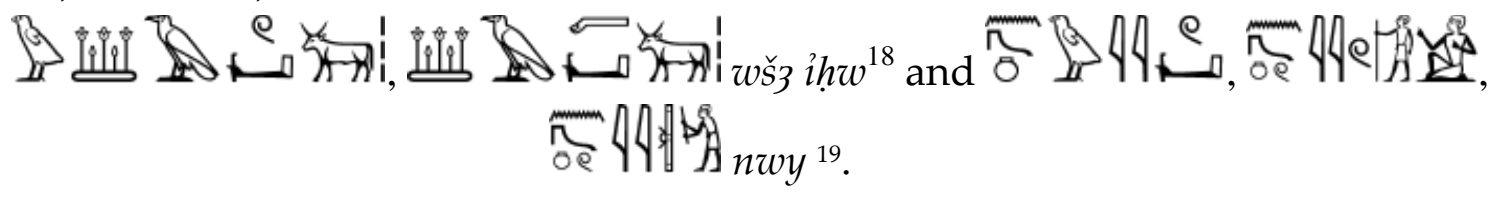

Artists were concerned with the physical and behavioral aspects of the numerous animals they represented, as shown by a survey of daily life scenes in private tombs. However, the artist's interest in depicting those characteristics varied from one animal to the other, most likely due to the animal's importance in Egyptian society.

The scenes of animal husbandry concentrated on large and small cattle, and to a lesser extent, on other animals, until the end of the Old Kingdom. Many rulers mentioned the enormous number of cattle they owned or cared for ${ }^{20}$. The representations of cattle-herdsmen from the Old Kingdom to the $20^{\text {th }}$ Dynasty focused on their role in agricultural pursuits. Furthermore, they addressed their personality traits, life cycle, and physical appearance.

Therefore, herdsmen could be identified by their appearance in tomb scenes. They were usually noticeably thin. They had to scrimp on food and personal comforts because they continuously worked with their charges. Their ages varied between the young, old, and elderly, and most of them were in good health, while a few of them were represented with a particular deformity ${ }^{21}$ [FIGURE 1].

\footnotetext{
${ }^{15}$ DAVIES 1948: PL.XXV.

16 LESKO 1982: 7-8; GARDINER 1957:447.

17 LESKO 1982: 8

${ }^{18}$ ERMAN \& GRAPOW (EDS.): Wb.1, 369, 7.

${ }^{19}$ ERMAN \& GRAPOW (EDS.): Wb.2, 5, 220.

${ }^{20}$ KANAWATI 1980: FIG.14.

${ }^{21}$ MAHRAN \& KAMAL 2016: 169-191.
} 


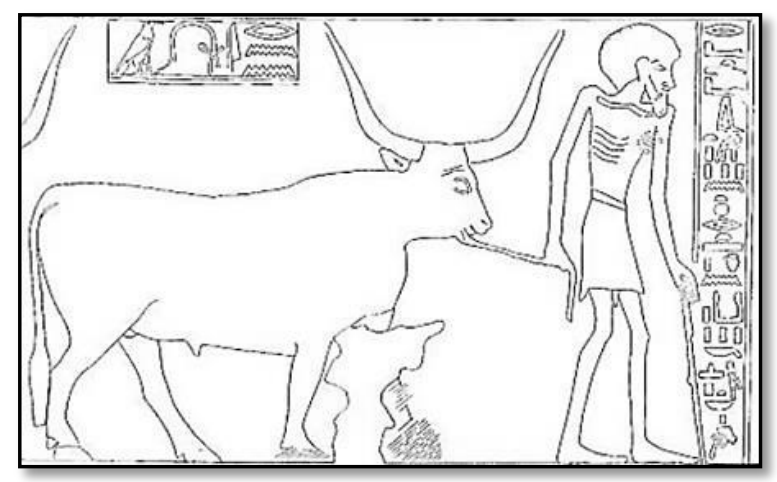

[FIGURE 1]. The Tomb-Chapel of Ukh-Hotp's Son Senbi. West wall-lower registers BLACKMAN 1915: PL.XI

Some herdsmen appeared with natural hair, others were bald or half-bald, and others wore wigs. Herdsmen, as commoners, were represented in a very realistic attitude, so natural baldness, if it existed, was exclusively for commoners in ancient Egypt. ${ }^{22}$ They carried a long stick and a bundle of pots and food over their shoulders while wearing their kilts folded in. Hairstyles and garment fashions could help identify different social groups, activities, and ages ${ }^{23}$.

An examination of wall scenes showed the activities of the herdsmen. They participated in many works, such as plowing the land, which usually showed some of them pushing on the handles of the plow while the others encouraged the animals. For example, a scene from the tomb of Antefoger (TT 60) showed two pairs of oxen pulling a plow each. The pair of oxen on the right turned their heads, and one bent a knee, but two herdsmen, one at the back with a stick and the other in front with a rope linked to a horn, had no intention of allowing the beasts to rest. A herdsman from each team pushed the plow forward ${ }^{24}$.

Supporting herds in fording rivers: A scene from Ty's tomb (Saqqara, the $5^{\text {th }}$ Dynasty), on the left (west) part of the north wall, depicted the crossing of a ford by a herd of cattle. Six herdsmen were divided among two papyrus craft, who arranged and managed the usually dangerous crossing ${ }^{25}$.

Milking: These scenes appeared in many tombs. For example, the tomb (G 2184) of Akhmerutnisut showed one of the peasants holding the calf while the other peasant was milking the cow, which looked in sorrow at its baby, and they tethered its back legs ${ }^{26}$.

Suckling: The most emotional scene appeared at the tomb of Baket III in Beni Hassan, which represented a young boy and a young calf simultaneously drinking milk

\footnotetext{
22 DAVIES 1925: PL.XXII; MEKHITARIAN 1997:21-28; ROBINS, 1999: 55-69; TASSIE 2011: 605-643.

23 TASSIE 2008: 136

${ }^{24}$ GARDINER \& DAVIES 1920: PL.V.

25 Wild 1953: Pl.XCIV/A; KANAWATI 1980: Fig.12; KANAWATI 1999: PL.55; BROVARSKI 2001:PL.96.

26 Ziegler1990: 143; NAVILLE 1913: PL.II; WreSZINSKI 1936: PL.89; SMITH 1949: FIG.79
} 
from the cow's udder, and the cow was represented affectionately licking its baby to be calm $^{27}$.

Giving birth: The scenes of the delivery of the cow appeared in many tombs with simple differences in the details. For example, the scene from the tomb of Niankhkhnum and Khnumhotep, the northern area of Saqqara, showed the delivery of the young calf in the presence of three herdsmen. One kneeled behind the cow to pull the frontal legs of the calf, another stood behind him, and the third stood before the cow. The artist here was clever enough to illustrate the cow's severe pain ${ }^{28}$.

Feeding the young cattle: For instance, a scene from the Mastaba (G2196) of Iasen, in the upper register of the north wall of the chapel, depicted a young bull with a muzzle over its head and a blanket over its back being fed by a squatting man ${ }^{29}$. In addition, the role that the herdsmen played in hauling the mummy by oxen and delivering the animals to the estate owners or bailiffs ${ }^{30}$ [FIGURE 2].

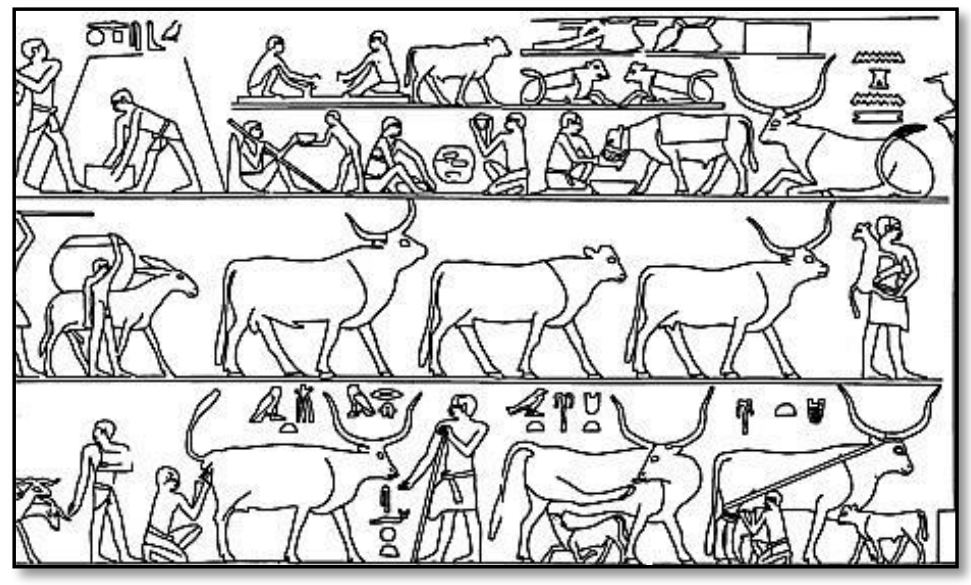

[FIGURE 2]. The Mastaba of Iasen (G2196) shows the activities of the cattle herdsmen SIMPSON 1980: 30

\section{The herdsman's hairstyle}

The herdsmen were usually bearded, while some appeared bald or half bald, and others wore a wig. In one of the scenes, one of the drovers appeared disheveled ${ }^{31}$. Wigs were regularly used in daily life or for ritualistic performances.

Baldness or greying hair was uncommonly depicted in tomb wall scenes, especially for the kings, princes, and nobles ${ }^{32}$.

It was radically different for the lowest classes of workers and commoners. They were depicted fairly realistically to emphasize the social distinctions between them and

\footnotetext{
27 DAVIES 1901: PL.XVII; DAVIES 1933: FIG.10; WeEKS 1994: FIG.34; BROVARSKI 2001: PL.42.

${ }_{28}^{2}$ DAVIES 1902: PL.XIX; WresZINSKI 1936: PL.17, 85; MOUSSA 1977: PL.76; ROTH 1995: FiG.204.

29 SIMPSON 1980: 30

30 SIMPSON 1980: PL.XXXVI.

31 PM: 286-289; DAVIES 1925: PL.XXIII; MEKHITARIAN 1997: 21-28.

32 TASSIE 2011: 605-643; DIMITRI 2010:1-2.
} 
their lords ${ }^{33}$. Baldness was known throughout Egyptian history from the Old Kingdom to the Ptolemaic period ${ }^{34}$. There were not less than 49 scenes of baldness representatives in ancient Egyptian wall scenes of herdsmen depicted in different contexts. A large number of scenes were situated in the tomb of $\mathrm{Ty}$, which had 22 scenes.

The 44 baldness scenes of herdsmen discovered in the Old Kingdom tombs were dated from the $4^{\text {th }}$ to the $6^{\text {th }}$ dynasties. Two baldness scenes of herdsmen were discovered in the tombs of the Middle Kingdom dated from the 11 th and $12^{\text {th }}$ dynasties. Three baldness scenes of herdsmen were discovered in tombs dating from the $18^{\text {th }}$ and $20^{\text {th }}$ Dynasties in the New Kingdom.

The scenes in the Old Kingdom tombs were divided as follows: (22) scenes in the tomb of $\mathrm{Ty}^{35}$, (6) Niankh-amun and Khnum-hotep ${ }^{36}$, (5) Kagemni ${ }^{37}$, (3) Iasen and Penmeru ${ }^{38}$, (2) Meres-ankh III $(G 7530)^{39}$, (2) Idut ${ }^{40}$, (2) Nefer and Khay ${ }^{41}$, (1) Ptahhotep ${ }^{42}$, (1) Ihy. The scenes of the Middle Kingdom tombs were (2) scenes from the tomb of Senbi I ${ }^{43}$. The scenes of the New Kingdom were divided as follows: (2) scenes from the tomb of Menna ${ }^{44}$ and (1) Paheri.

Many models of representation related to baldness figures in ancient Egyptian private tombs reflected their different types of portrayal. But the most common was the depiction of baldness on the forehead, while the rest of the head was full of hair. The hair in this style was short with heavy locks. This hairstyle was portrayed again in the late period ${ }^{45}$ [FIGURE 3].

\footnotetext{
33 ROBINS 1999: 55-69.

34 TASSIE 2009: 459-536.

35 WILD 1953: PL.26; JONCKHEERE 1948: 28; WEEKS 1970: 75.

36MOUSSA \& ALTENMÜLLER 1977: PL.17; EVANS \& WOODS 2016: 55-72.

37WALSEM 2005: 45; YVONNE \& PAOLO 2006: 496-7.

38 WOOD 2011: 314-319.

${ }^{39}$ DUNHAM \& SIMPSON 1974: FIG.4.

${ }^{40}$ KanaWATI \& ABDER-RAZI 2003: Pl.71.

${ }^{41}$ OSER 2011:42, PL.11.5

42MAHRAN \& KAMAL 2016: 169-191.

${ }^{43}$ BLACKMAN 1915: KANAWATI \& EVANS 2018: 18-34.

${ }^{44}$ HARTWIG 2001: 27

${ }^{45}$ KANAWATI \& WOODS 2009: Pl.116
} 


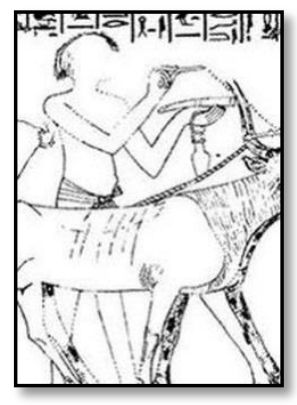

A

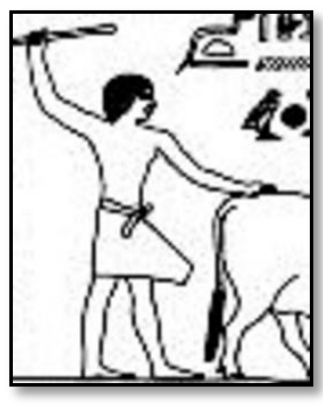

B

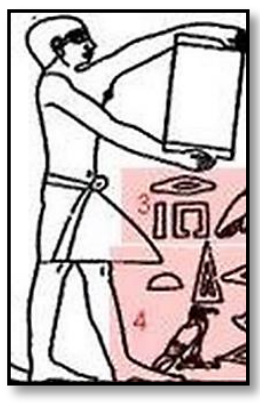

C

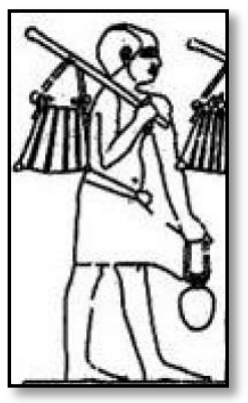

D

[FIGURE 3]. A-The tomb of Nebamon, TT18

Https://www.osirisnet.net/popupImage.php?img=/tombes/nobles/nebamon_ipouky181/photo/nebamon_ipouky_i s_24.jpg\&lang=en\&sw=1366\&sh=768, Accessed January 13, 2022

B- The mastaba of Ptahhotep-D64

Https://www.osirisnet.net/popupImage.php?img=/mastabas/akhethtp_ptahhtp/photo/ptahhtp_10_ag.jpg\&lang=en \&sw=1366\&sh=768, Accessed January 13, 2022

C-D- Mastaba of Ti. WILD 1966: PL.CLXVII.

Https://www.osirisnet.net/popupImage.php?img=/mastabas/ty/photo/ty_CHS_centre_R5.6.gif\&lang=en\&sw=1366 \&sh=768, Accessed January 13, 2022

\section{The herdsman's costume}

The costume could be a powerful tool in the identification of the herd drivers, their function, and even their place in the social hierarchy. Egyptians used clothing in art as significant signs of position and occupation, which would be easily identified by the viewer ${ }^{46}$.

The cattle herdsmen were always dressed in either a simple kilt or naked ${ }^{47}$. If they wore kilts, they were always short and never had the starched pleats or sharp point at the knee shown in higher-ranking clothes ${ }^{48}$.

In the Mastaba of Ty, the central part of the south wall of the chapel, Register 6, the herdsmen are easily recognizable by their looks and clothes. The third beast of the register is followed by two aged herdsmen dressed in kilts with forwarding projections ${ }^{49}$ [FIGURE 4].

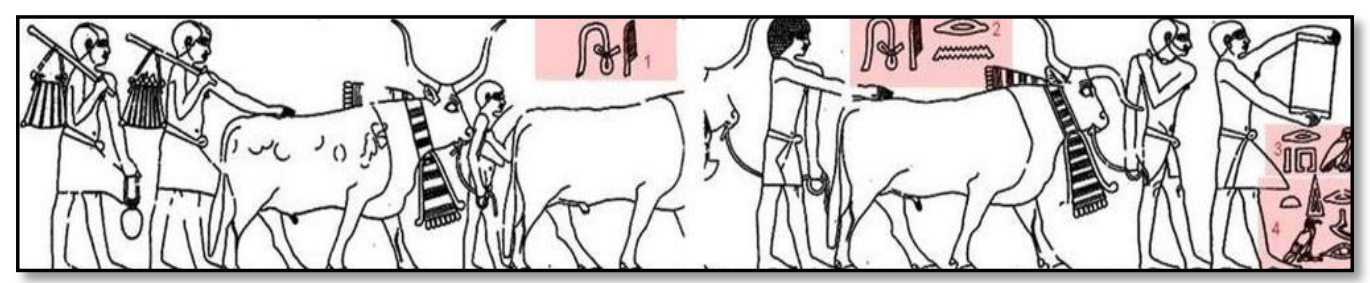

[FIGURE 4]. Mastaba of Ty. WILD 1966: Pl.CLXVII

https:/www.osirisnet.net/popupImage.php?img=/mastabas/ty/photo/ty_CHS_centre_R5.6.gif\&lang=en \&sw=1366\&sh=768, Accessed January 13, 2022

\footnotetext{
${ }^{46}$ Hagseth 2015: 61; BRIER \& HobbS 2008: 127; Romano 1990: 9; PeCK 2013: 49.

${ }_{47}$ STEINDORFF 1913: PL.118; BLACKMAN 1915: PL.IV; VANDIER 1969: FIG 39-40.

${ }^{48}$ MONTET 1981: 74; BRIER \& HOBBS 2008: 127, 132-133.

${ }^{49}$ HAGSETH 2015: 62; PECK 2013: 56.
} 
This usually signified their higher status ${ }^{50}$. Likewise, on the Mastaba of Iasen (G2196), the upper register of the east wall, the third and fourth characters appeared with their special loincloths of herdsmen, presenting themselves in the attitude of respect $^{51}$ [FIGURE 5].

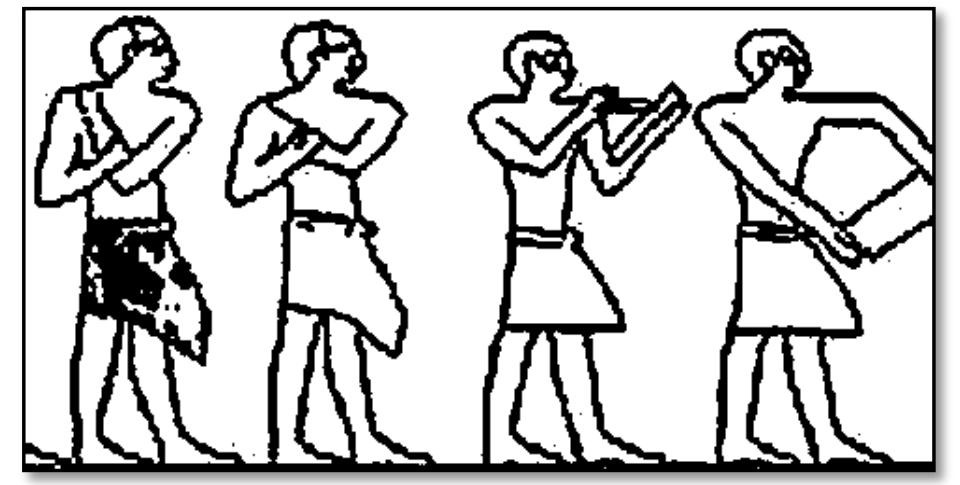

[FIGURE 5]. Mastaba of Iasen (G2196). SIMPSON 1980: PL.XXXVI.

Https://www.osirisnet.net/popupImage.php?img=/mastabas/iasen/photo/iasen_g2196_simpson_fig_31. gif\&lang=en\&sw=1366\&sh=768, Accessed January 13, 2022

In the Mastaba of Ty, the central part of the south wall of the chapel, Register 5, the herdsmen of this register did not wear much, and their clothing only covered their buttocks [FIGURE 6].

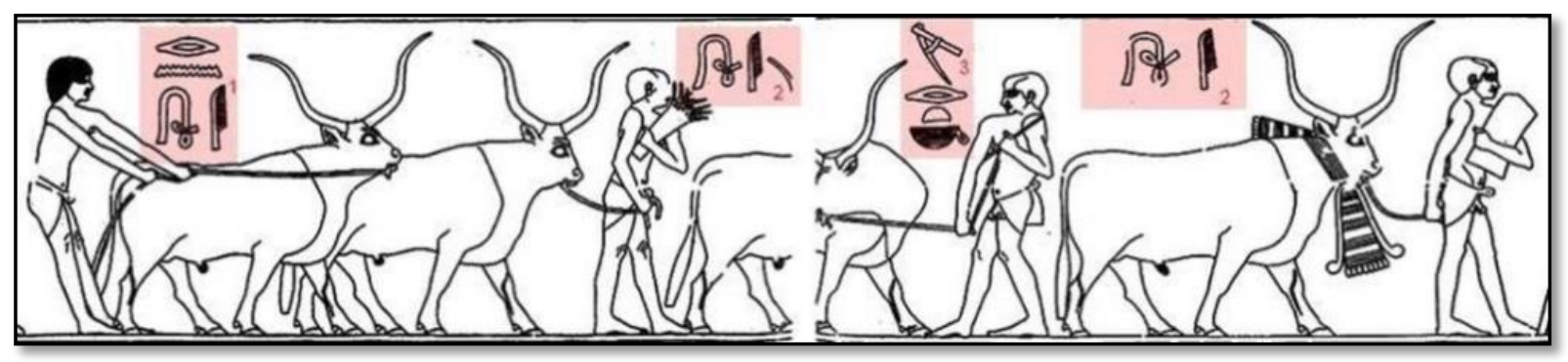

[FIGURE 6]. Mastaba of Ti. WILD 1966: PL.CLXVII

In the Mastaba of Ty, the central part of the south wall of the chapel, Register 2, a large «OX» is pushed from behind by an aide. This herdsman wears a projecting kilt with vertical stripes. At the left edge of the register is a herdsman wearing a striped projecting kilt [FIGURE 7].

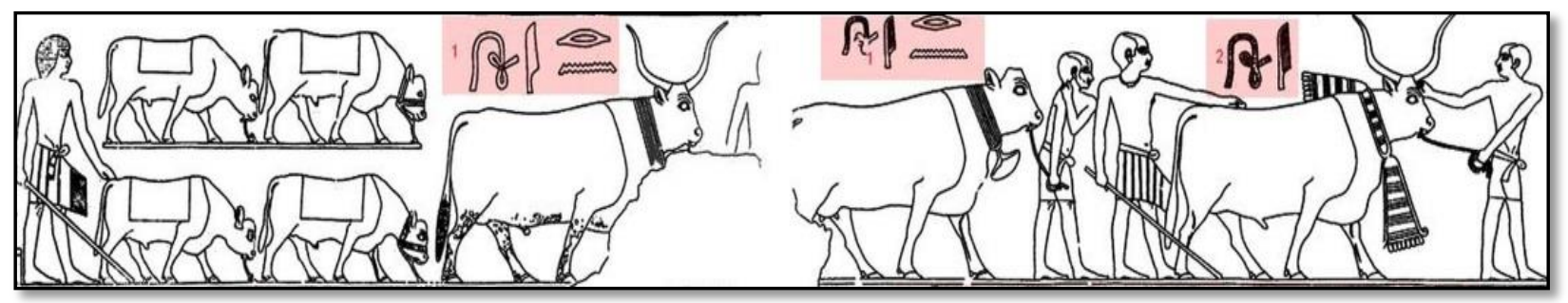

[FIGURE 7]. Mastaba of Ty. WILD1966: PL.CLXIX.

https://www.osirisnet.net/popupImage.php?img=/mastabas/ty/photo/ty_CHS_centre_R5.6.gif\&lang=en\&sw=1366 $\&$ sh=768, Accessed January 13, 2022

\footnotetext{
50 PORTER \& MOSS: PM III.': 468-469; WILD 1959: 101-113; STEINDORFF 1913: 118

51 PORTER \& MOSS: PM III.1: 82; SIMPSON 1980: PL.158
} 
In the Mastaba of Ty, the north wall of the chapel, the right (east) part of the wall, register 2, the scene of the crossing of the ford shows three naked herdsmen ${ }^{52}$ [FIGURE 8].

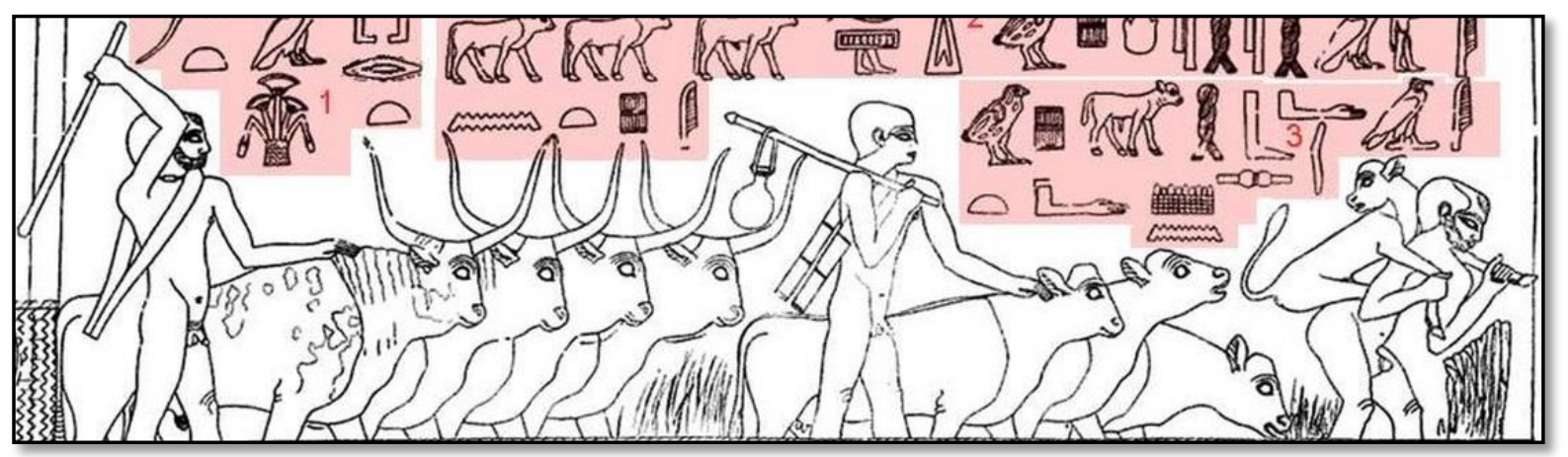

[FIGURE 8]. Mastaba of Ty. WILD 1953: PL.LXXX.

https://www.osirisnet.net/popupImage.php?img=/mastabas/ty/photo/ty_CHN_R2.gif\&lang=en\&sw=13 $66 \&$ sh=768, Accessed January 13, 2022

In the Mastaba of Meryteti, also known as Meri chamber C1, five registers are superimposed in the lower left corner. Each register depicts two animals with two or three men accompanying them. These wear short or projecting kilts, except for one (placed at the front of the next-to-bottom register) who wears the kilt associated with a master herdsman. He is described as «the $k a$-servant, the overseer of the house, Merinen ${ }^{53}$ [FIGURE 9].

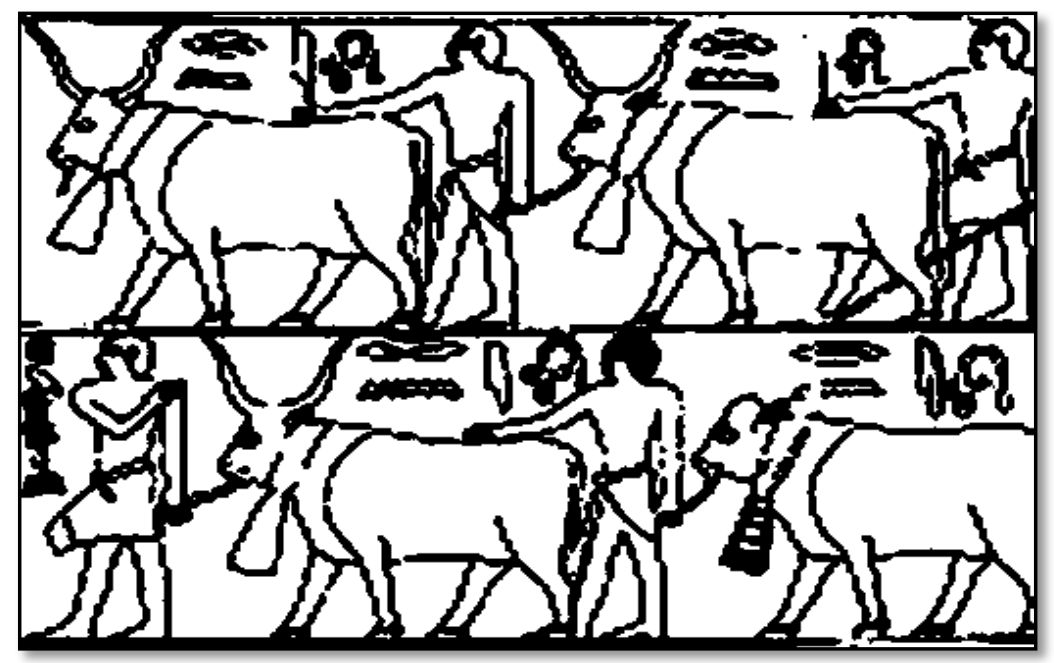

[FIGURE 9]. Mastaba of Meryteti

Https://www.osirisnet.net/popupImage.php?img=/mastabas/meryteti/photo/mrytti_c1_ew.gif\&lang=en $\& s w=1366 \& s h=768$, Accessed January 13, 2022. 
In the tomb of Menna (TT69), the south wall -East side of the wall-upper register, there are two pairs of cattle tied by the horns. They are under the control of a herdsman who holds a stick and wears a white kilt [FIGURE 10].

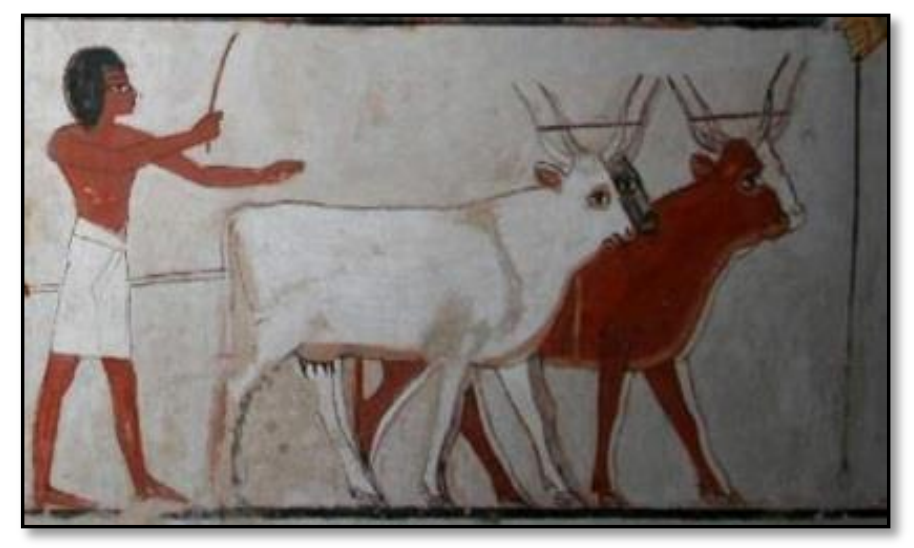

[FIGURE 10]. Left Side, Long Hall, Funeral Procession from the Tomb of Menna (TT 69) HARTWIG 2013: 68.

In the tomb of Amenemhat (TT 340), the site of Deir el-Medina, dating from the early $18^{\text {th }}$ Dynasty, the lower registers of the north wall depicts the funeral procession. There are four porters with chests at the head, six porters with offerings facing the mourners, and five men carrying the catafalque preceded by two cattle and a herdsman. All porters and the herdsman are clothed in the same way: Simple short loincloths and short wigs covering their ears ${ }^{54}$ [FIGURE 11].

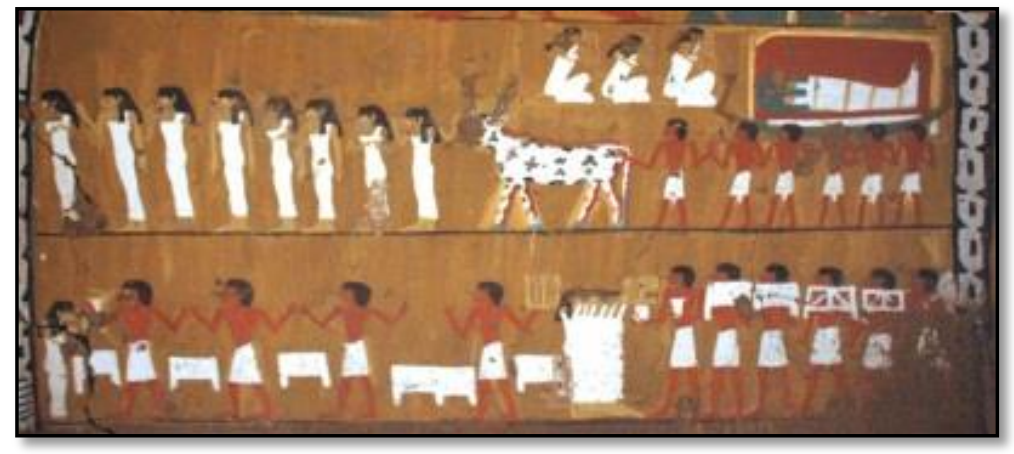

[FIGURE 11]: A scene shows a herdsman and offering porters from the tomb of Amenemhat (TT 340)

Https://www.osirisnet.net/popupImage.php?img=/tombes/artisans/amenemhat340/photo/amn340_a31.j pg\&lang=en\&sw=1366\&sh=768, Accessed January 13, 2022.

Another scene, from the tomb of Pairy (TT 139) in Thebes, contains the funeral procession to Pairy's final resting place. The procession consists of twenty-five individuals. Some men have shaved heads, and others wear wigs, carrying funerary goods for the deceased. Two cowherds in white kilts lead four oxen of white, brown, and black with the aid of switches raised above their heads. The oxen's horns are tied together with a rope connected to a wooden sled that carries Pairy's sarcophagus.

\footnotetext{
${ }^{54}$ CHERPION 1999: 31-39.
} 
Eight men follow closely behind the oxen in rows of two, holding the ropes with both hands to assist in pulling the weight of the bark. The herdsmen and the other men are dressed in the same way: basic short loincloths ${ }^{55}$ [FIGURE 12].

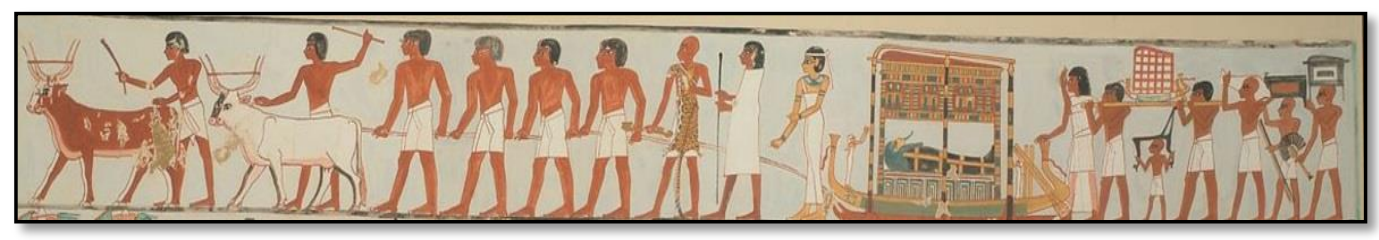

[FIGURE 12]. A scene shows two herdsmen, 8 rope holders and offering porters from the tomb of Pairy (TT 139) in Thebes; O'NeILl 2015: Pl.3.27.3.28

\section{The herdsman's job and tools}

The herdsmen appeared in daily life and funeral scenes in several situations. Through these scenes, various tools appeared to control the herd, such as the rope, stick, whip, and vessels for water or milk in the funeral scenes.

The scenes showed different positions for using the stick: the front position, the top of the head (horizontal), and the back position. At the same time, the positions of the hands changed, either holding a grazing tool or placing it in the direction of the cows belonging to the herd. The following tables show the different positions of using herdsman's tools.

\footnotetext{
${ }^{55}$ PORTER \& MOSS: PM, 252; VIREY 1894: 581-90; O'NeILL 2015: 43- 44, PL.3.27, 3.28.
} 


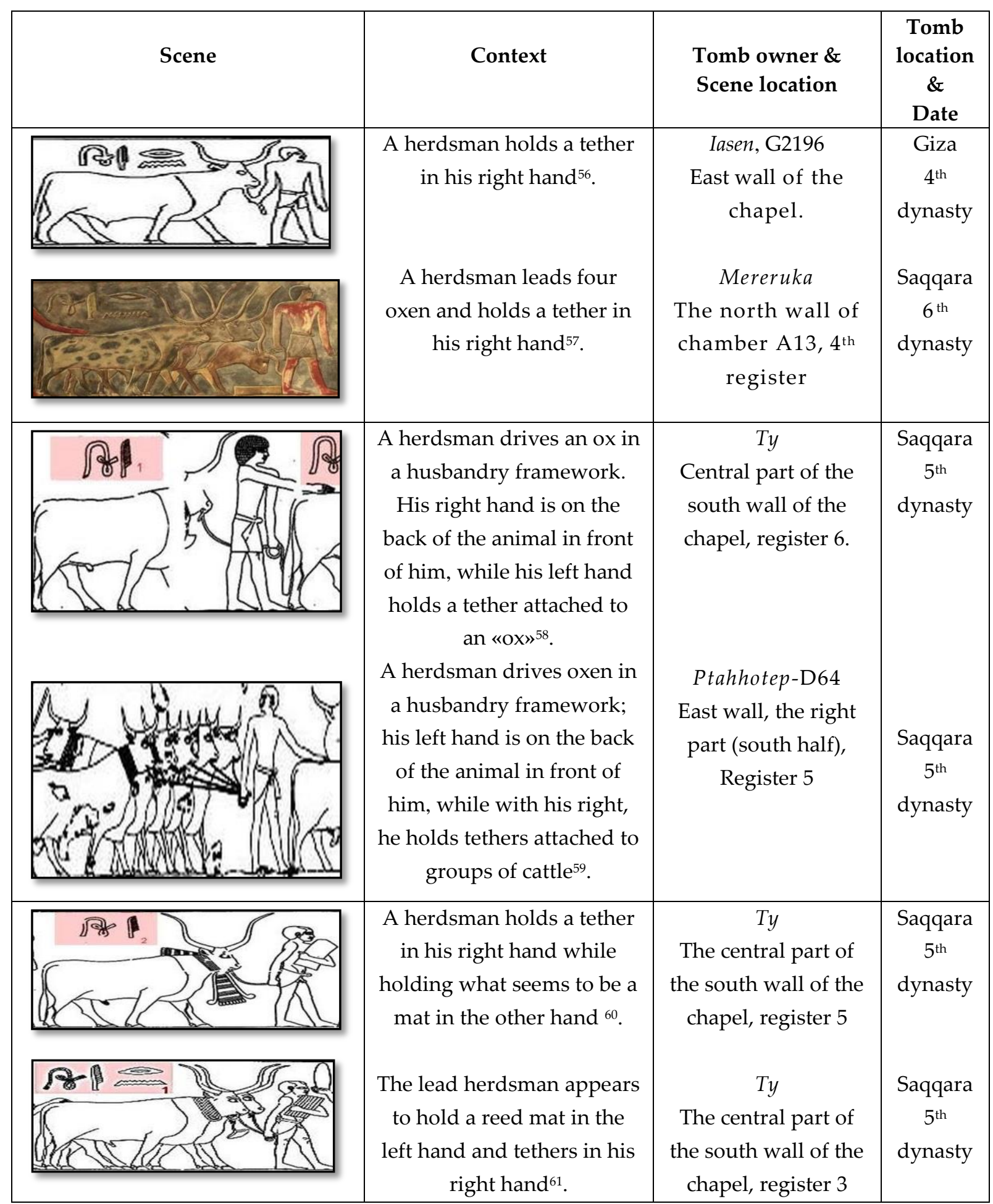

\footnotetext{
56 PORTER \& MOSS: PM III 2: 525-534; SIMPSON 1980: PL.XXXVI.

${ }^{57}$ DUELL 1938: PL. 152

58 WILD 1966: PL.CLXVII.

${ }^{59}$ DAVIES 1901: PL.XXI

60 WILD 1966: PL.CLXVII.

${ }^{61}$ WILD 1966: PL. CLXVIII.
} 


\begin{tabular}{|c|c|c|c|}
\hline$a_{0}$ & $\begin{array}{l}\text { A herdsman holds a tether } \\
\text { in his right hand and a } \\
\text { small bundle of hay in his } \\
\text { left hand }{ }^{62} \text {. } \\
\text { A herdsman appears, } \\
\text { looking left, with his right } \\
\text { hand pulling a large fat bull } \\
\text { and his left hand holding a } \\
\text { bundle of fodder for the } \\
\text { bull. Except for his left } \\
\text { knee, bent backward, the } \\
\text { herdsman appears to be in } \\
\text { good health } 63 .\end{array}$ & $\begin{array}{l}\text { Ty } \\
\text { The central part of } \\
\text { the south wall of the } \\
\text { chapel, register } 5 \\
\text { Ptah-hotep } \\
\text { East wall, the right } \\
\text { part (south half), } \\
\text { Register } 6\end{array}$ & $\begin{array}{l}\text { Saqqara } \\
5^{\text {th }} \\
\text { dynasty } \\
\text { Saqqara } \\
5^{\text {th }} \\
\text { dynasty }\end{array}$ \\
\hline & $\begin{array}{c}\text { A herdsman leads a «young } \\
\text { ox». His left hand is on his } \\
\text { right shoulder, while his } \\
\text { right hand holds a rope }{ }^{64} \text {. } \\
\text { A herdsman leads a group } \\
\text { of cattle. His left hand is on } \\
\text { his right shoulder, while } \\
\text { his right hand holds } \\
\text { tethers }{ }^{65} \text {. }\end{array}$ & $\begin{array}{c}\text { Ty } \\
\text { The central part of } \\
\text { the south wall of the } \\
\text { chap, register } 6 \\
\text { Ptah-hotep } \\
\text { East wall, the right } \\
\text { part (south half), } \\
\text { Register } 5 .\end{array}$ & $\begin{array}{l}\text { Saqqara } \\
5^{\text {th }} \\
\text { dynasty } \\
\text { Saqqara } \\
5^{\text {th }} \\
\text { dynasty }\end{array}$ \\
\hline & $\begin{array}{l}\text { A bald herdsman with a } \\
\text { back knee deformity } \\
\text { catches an ox by a rope in } \\
\text { his left hand while holding } \\
\text { a bag in the other hand in } \\
\text { an animal husbandry } \\
\text { context }^{66} \text {. }\end{array}$ & Ihy & $\begin{array}{c}\text { Saqqara } \\
5^{\text {th }} \\
\text { dynasty }\end{array}$ \\
\hline & $\begin{array}{l}\text { The herdsman pulls the } \\
\text { cow with a rope around his } \\
\text { neck to control } \text { it }^{67} \text {. } \\
\text { The animal moves its head } \\
\text { away from its herdsman, } \\
\text { who faces it with both } \\
\text { hands clutching the rope }{ }^{68} \text {. }\end{array}$ & $\begin{array}{l}\text { Iasen, G2196 } \\
\text { East wall of the } \\
\text { chapel. } \\
\text { Ty } \\
\text { The central part of } \\
\text { the south wall of the } \\
\text { chapel, register } 5\end{array}$ & $\begin{array}{c}\text { Giza } \\
4^{\text {th }} \\
\text { dynasty } \\
\text { Saqqara } \\
5^{\text {th }} \\
\text { dynasty }\end{array}$ \\
\hline
\end{tabular}

\footnotetext{
${ }^{62}$ WILD 1966: PL.CLXVII.

63 Paget \& Pirie 1896; DAVIES 1901: PL. XXI.

64 WILD 1966: PL.CLXVII.

${ }^{65}$ DAVIES 1901: PL..XXI.

${ }^{66}$ MAHRAN \& KAMAL 2016: 169-191.

${ }^{67}$ SIMPSON 1980: PL.XXXVI.

68 WILD 1966: PL.CLXVII.
} 


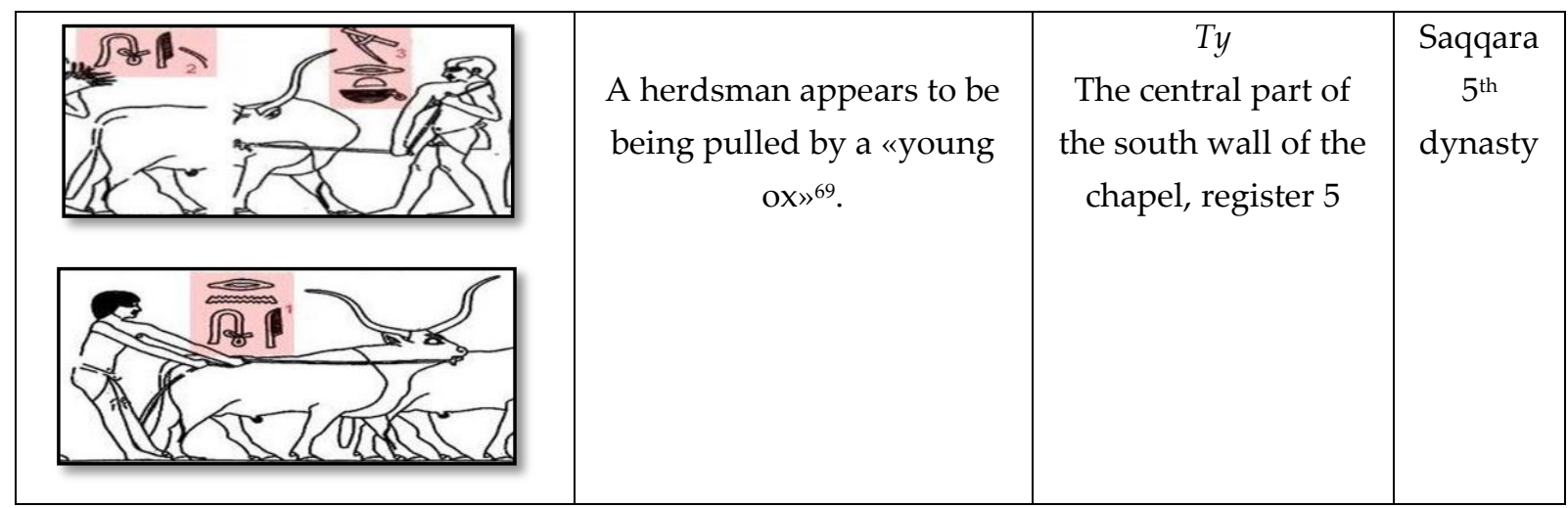

[TABLE 1]. Different positions of the rope and hands representations $\odot$ done by the author

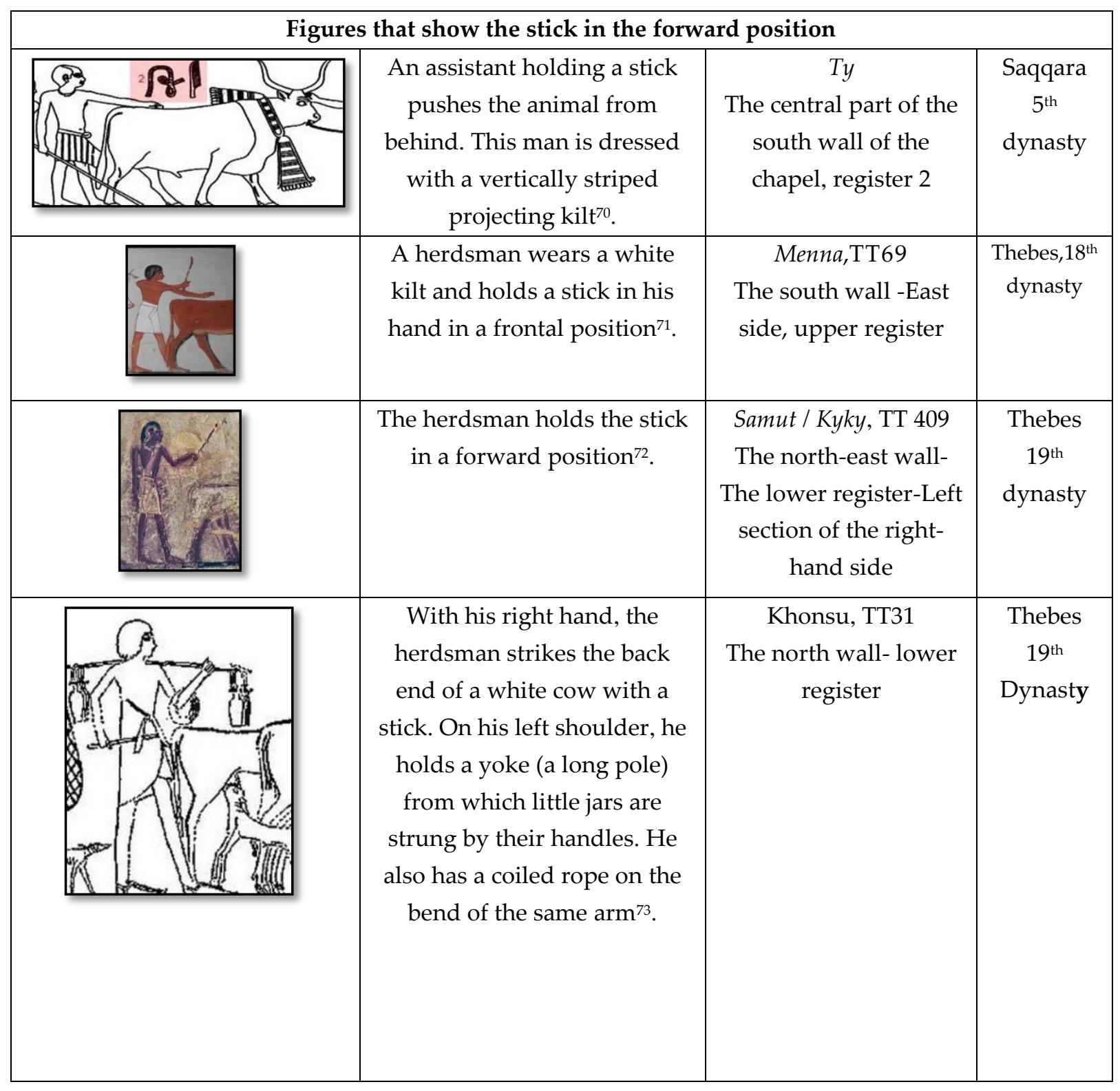

${ }^{69}$ WILD 1966: PL.CLXVII.

70 WILD 1966: PL.CLXIX.

71 PORTER \& MOSS: PM: 134-139; HODEL-HOENES 2000: 85-111; HARTWIG 2001: 398-407

72 PORTER \& MOSS: PM: 461-462; VERNUS 1978: 115-146; ABDUL-QADER 1966: PL.XXVIII.

${ }^{73}$ PORTER \& MOSS: PM: 47-49; DAVIES \& GARDINER 1948: 31-41; VANDIER 1969: PL.126.1. 


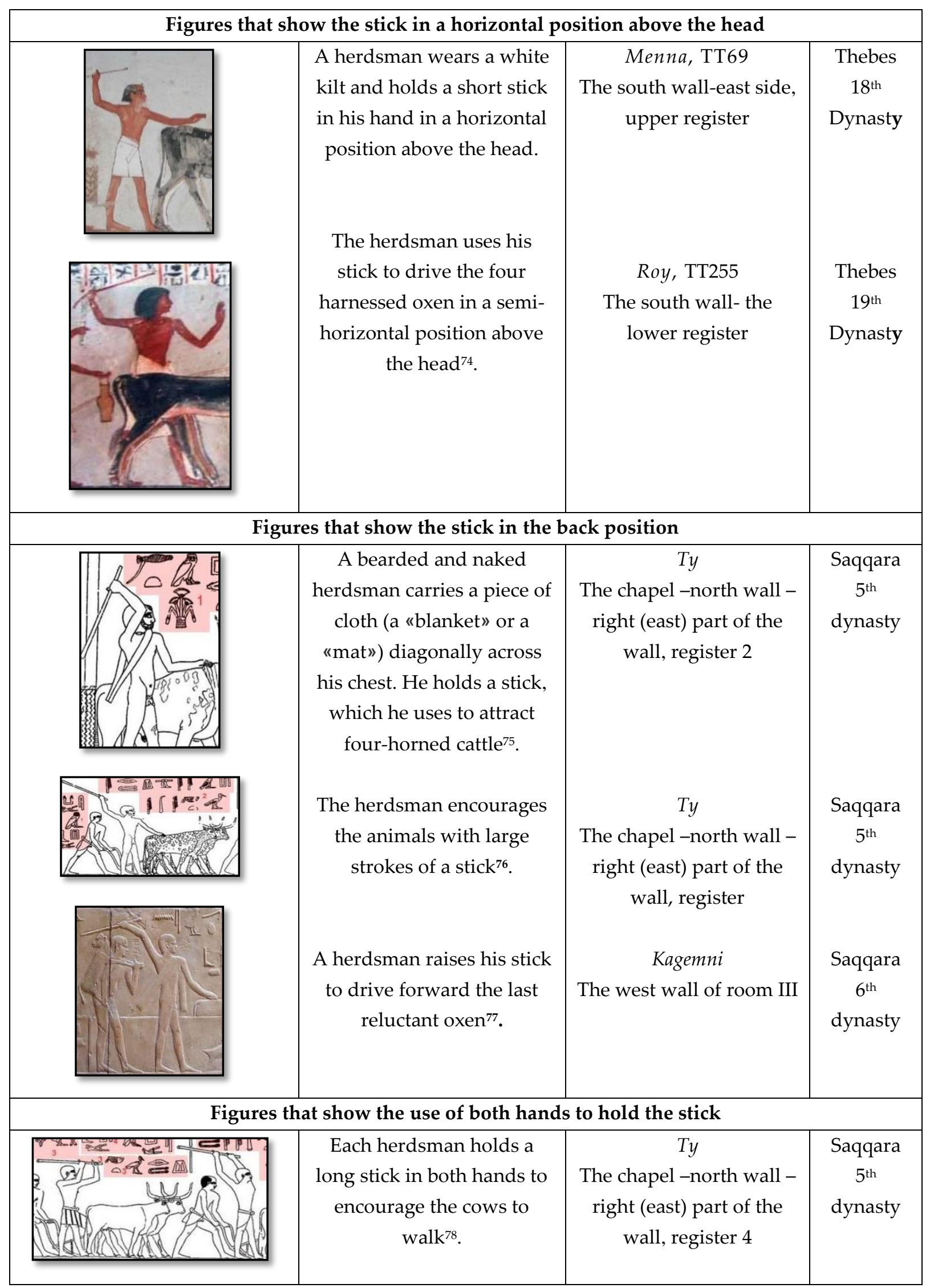

74 PORTER \& MOSS: PM: 151; GEORGE, MARCELLE \& ETIENNE 1928: Fig.7.

${ }^{75}$ WILD 1953: PL.LXXX; WRESZINSKI 1936: PL.44.

${ }^{76}$ WILD 1953: PL. LXXVIII.

77 PORTER \& MOSS: PM III²: 521-525; BISSING 1905-1911; YvONNE \& PAOLO 2006.

${ }^{78}$ WILD 1953: PL. CXII. 


\begin{tabular}{|c|c|c|c|}
\hline 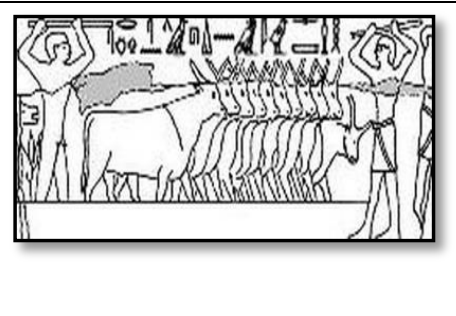 & $\begin{array}{l}\text { During the crossing of a } \\
\text { ford, two herdsmen keep } \\
\text { an eye on their animals. } \\
\text { The one on the left is in the } \\
\text { water, while the other is on } \\
\text { the other side of the river }{ }^{79} \text {. }\end{array}$ & $\begin{array}{c}\text { Mereruka } \\
\text { The east wall of } \\
\text { chamber A13,scene 3, } \\
\text { the 1st register }\end{array}$ & $\begin{array}{c}\text { Saqqara } \\
6^{\text {th }} \\
\text { dynasty }\end{array}$ \\
\hline
\end{tabular}

[TABLE 2]. Different positions of the stick representations $\mathbb{C}$ done by the author

\begin{tabular}{|c|c|c|c|}
\hline & $\begin{array}{c}\text { A disheveled herdsman thinly } \\
\text { sprinkles milk from a jar onto the } \\
\text { path of the animals }{ }^{80} .\end{array}$ & $\begin{array}{l}\text { Nebamon, TT181 } \\
\text { West wall-upper } \\
\text { register }\end{array}$ & $\begin{array}{l}\text { Thebes } \\
18^{\text {th }} \\
\text { dynasty }\end{array}$ \\
\hline & $\begin{array}{l}\text { The herdsman carries a water } \\
\text { vessel, which could be used to } \\
\text { help the sled runners }{ }^{81} \text {. }\end{array}$ & $\begin{array}{c}\text { Userhat, TT56 } \\
\text { Chamber b-west } \\
\text { wall (long wall, } \\
\text { on the right }\end{array}$ & $\begin{array}{l}\text { Thebes } \\
18^{\text {th }} \\
\text { dynasty }\end{array}$ \\
\hline$\frac{\pi}{21}$ & $\begin{array}{l}\text { A herdsman stimulates a couple } \\
\text { of oxen with the help of a whip }{ }^{82} \text {. }\end{array}$ & $\begin{array}{c}\text { Paheri } \\
\text { West wall -North } \\
\text { End: Funeral } \\
\text { Rites }\end{array}$ & $\begin{array}{c}\text { Thebes } \\
18^{\text {th }} \\
\text { Dynasty }\end{array}$ \\
\hline
\end{tabular}

[TABLE 3]. Representations of various drovers' tools $\mathbb{C}$ done by the author

Finally, some examples of the speech captions are presented to explore the language of the conversation, their relationship at work, their knowledge of the nature of cows, and their ability to lead the herd, whether these conversations are directed at each other, their assistants, or the herd.

\footnotetext{
${ }^{79}$ DUELL 1938: PL.168

80 DAVIES 1925: PL.XXIII; MEKHITARIAN 1997: 21-28

81 PORTER \& MOSS: PM 111-113; BEINLICH-SEEBER \& SHEDID 1987: TAF.15

82 PORTER \& MOSS: PM 5: 177-181; TYLOR \& GRIFFITH 1894: PL.V
} 


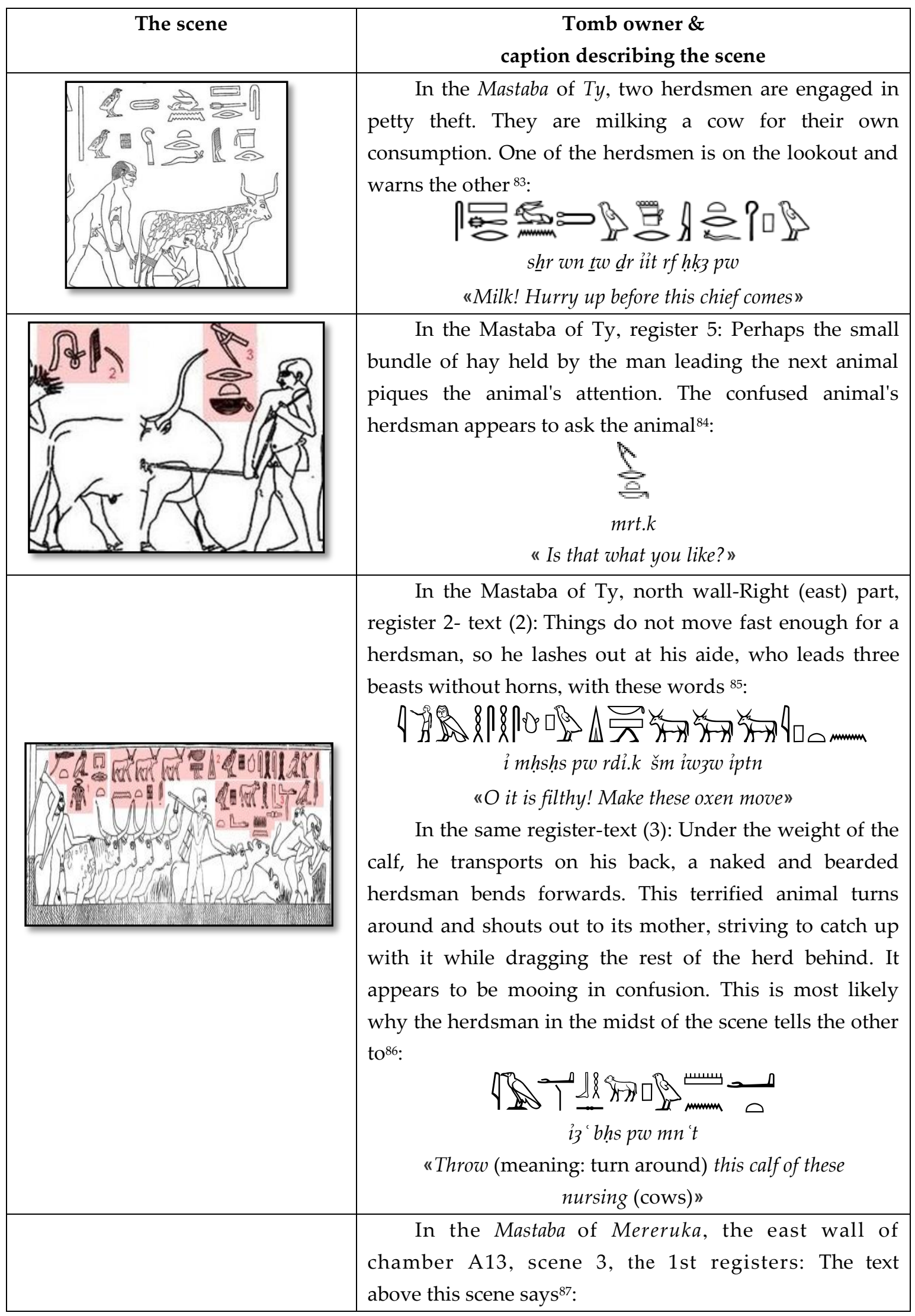

\footnotetext{
83 WILD 1953: PL.CXII.

${ }^{84}$ WILD 1966: PL.CLXVII

${ }^{85}$ WRESZINSKI 1936: PL.. 44

${ }^{86}$ WILD 1953: PLS. LXXX B, LXXXI \& CXIV.

${ }^{87}$ DUELL 1938: PL.168
} 


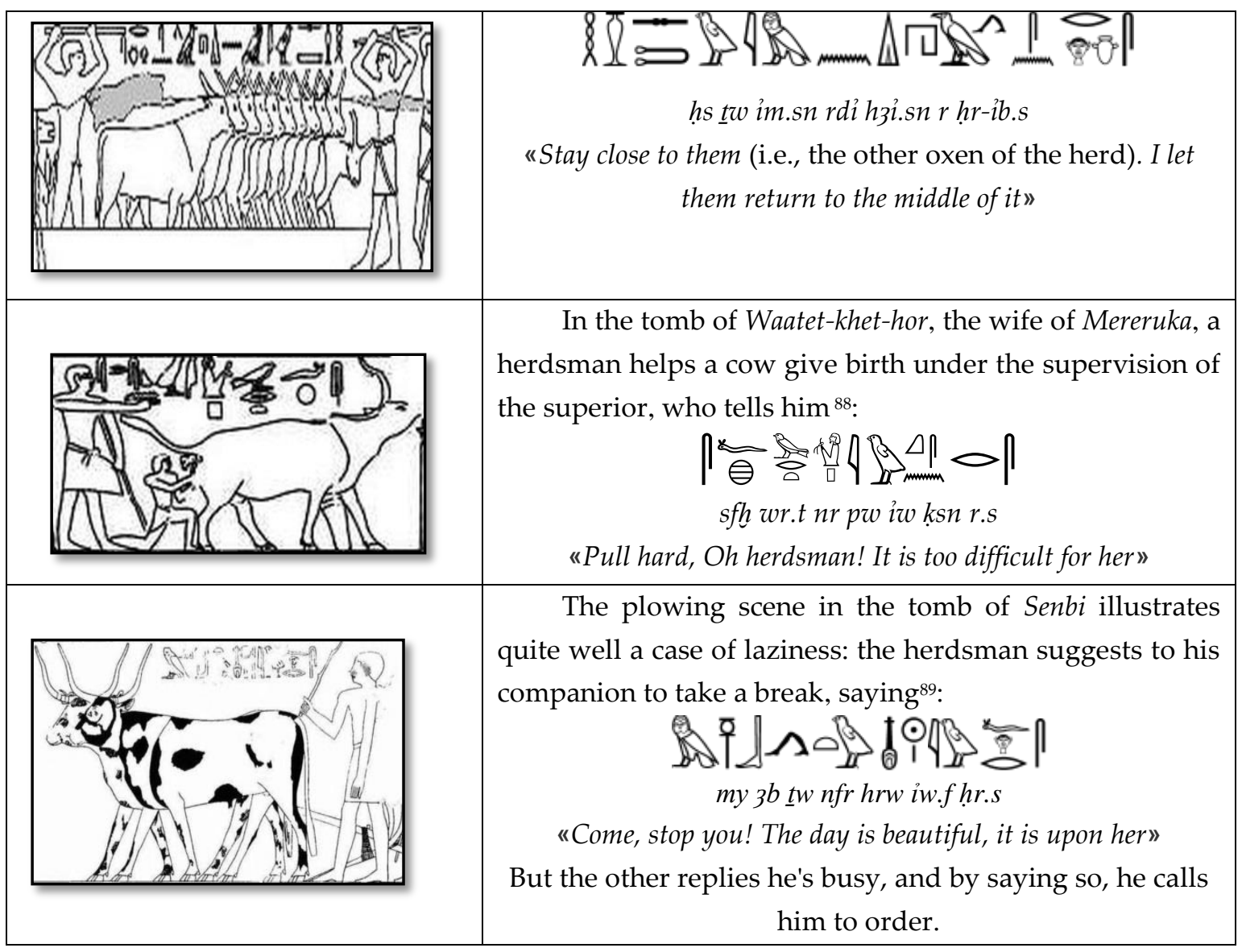

[TABLE 4]. Examples of the captions describing cattle herdsmen scenes $\odot$ done by the author.

The participants in these dialogues were either common herdsmen or their superiors, or even animals. The herdsman's scenes expressed their natural lives and were characterized by realism and simplicity. They indicated their awareness of the nature of the cows and their innate instinct.

The good working relationship between the herdsmen was depicted in the first and sixth scenes. The first scene displayed them arranging to get milk for themselves without their boss's knowledge, while the sixth scene depicted one of them inviting the other to take a break and enjoy the beautiful day.

Other scenes demonstrated the herdsman's awareness of the cow's nature and instincts. The herdsman's question in the second scene, directed at the cow, confirmed that he knew the reason for its return because of the hay. The third scene also depicted his experience with cows' maternal instincts. In addition, the fifth scene depicted the herdsman's mercy toward the cow when the superior instructed the herdsman to assist her throughout the giving birth.

Furthermore, the first text of the third scene and the fifth scene highlighted his ability to lead the herd and control its speed.

\footnotetext{
${ }^{88}$ KANAWATI \& ABDER-RAZIQ 2008: 56

${ }^{89}$ BLACKMAN 1914: 3, Pl.III; KANAWATI \& EVANS 2017: Pl.79
} 
Most of the conversations between the herdsmen were in imperative form due to the nature of their work, whether collective or individual, which required constant direction to undertake a task, either leading or assisting the herd, or demanding the performance of a task between the chief and the herdsmen, or the herdsmen and their aides $^{90}$.

\section{CONCLUSION}

From the Old Kingdom to the $20^{\text {th }}$ Dynasty, a study of daily life scenes in private tombs revealed that artists were well-versed in the physical and behavioral characteristics of the herdsmen they depicted.

Recording the herdsmen scenes reached its peak during the Old Kingdom, and most of these scenes were dominated by a basic characteristic: simplicity and realism, which was, in turn, due to the basis of their job as workers.

These herdsmen appeared through the scenes of daily life of all ages: the old, the mature, and the young. These scenes also highlighted their hairstyles, physical health, and sometimes physical disability, which did not prevent them from performing their job duties at all. Their social rank was evident through their clothes, which played an important role in discovering their roles. Various means for controlling the herd appeared in these scenes, including the rope, stick, and whip. These scenes were common in various settings, including the front, back, and upper head, for individual cow sightings or in groups to demonstrate the herdsmen's proficiency in controlling the herd's walks.

Moreover, the scenes depicting the herdsman's dialogue were crucial in revealing the herdsman's individual characteristics. Cooperation, compassion, awareness of the nature of animals and their impulses, and the ability to control the herd were all characteristics.

90 Gardiner 1957: § 313; MAlaise \& WinAND 1999: § 726, 840; Allen 2014: § 16.6; MouSSA \& ALTENMÜLLER 1977: PL.10; VERNUS 2010: 77 


\section{Naglaa Fathy Shehab}

\section{BIBLIOGRAPHY}

ABDUl-QADER, M.: «Two Theban tombs: Kyky and Bak-en-Amun», ASAE 59, 1966.

Allen, J.P.: Middle Egyptian: An Introduction to the Language and Culture of Hieroglyphs, $3^{\text {rd }}$ revised and reorganized ed., Cambridge, 2014.

Assmann, J.: The Mind of Egypt: History and Meaning in the Time of the Pharaohs, Translated by ANDreW JENKINS, New York (Metropolitan Books) 2002.

Bailleul-LeSuer, R., (ed.): Between Heaven and Earth: Birds in Ancient Egypt, Chicago (The Oriental Institute of the University of Chicago) 2012.

BeInLICH-SeEBER, C. \& SHEDID, A.: Das Grab des Userhat (TT 56), Mainz (Philipp von Zabern) 1987.

BISSING, F.W.: Die Mastaba des Gem-ni-kai, Berlin, 1905-1911

BLACKMAN, A.: The Rock Tombs of Meir, part I: The Tomb-Chapel of Ukh-Hotp's Son Senbi, ASEg 22, London (William Clowes and Sons) 1914.

BLACKMAn, A.: The Rock Tombs of Meir II, The Tomb-chapel of Ukhhotep son of Ukhhotep and Mersi (B, Nro.4), London (Egypt Exploration Fund) 1915.

BREWER, D.: «Hunting, Animal Husbandry and Diet in Ancient Egypt», in A History of the Animal World in the Ancient Near East, Edited by BILLIE JeAn ColLINS, Leiden (Brill) 2001.

BRIER, B. \& HOBBS, H.: Daily Life of the Ancient Egyptians, 2nd, London (Greenwood Press) 2008.

BrovarsKi, E.:The Senedjemib Complex I: The Mastabas of Senedjemib Inti (G 2370), Khnumenti (G 2374), and Senedjemib Mehi (G 2378), Giza Mastabas VII, Boston (Museum of Fine Arts) 2001.

BuDGE, E.A.: Hieroglyphic Vocabulary to the Theban Recension of the Book of the Dead: with an index to all the English Equivalents of the Egyptian words, London (KEGAN PAUL, Trench, Trubner \& Co,) 1911.

Cherpion, N., Deux tombes de la XVIII Dynastie à Deir el-Medina: №s 340 (Amenemhat) et 354 (Anonyme), MIFAO 114, Cairo (Institut français d'archéologie orientale) 1999.

DARESSY, G.: «Le mastaba de Mera», in 'Mémoires présentés à l'Institut Égyptien, vol.3, Cairo, 1898.

DAVIES, N. de, G.: The mastaba of Ptahhetep and Akhethetep at Saqqareh, part II, London (London Boston, Mass) 1901

DAvies, N. de, G.: The Rock Tombs of Deir El Gebrâwi: Tomb of Zau and Tombs of the Northern Group, Archaeological Survey of Egypt Memoir XI, London, 1902.

Davies, N. de, G.: The Tomb of the Two Sculptors at Thebes, Robb de Peyster Tytus Memorial Series, vol.4, New York (Metropolitan Museum of Art) 1925.

DAVIES, N. de, G.: « The Graphic Work of the Expedition at 1931-1932», BMMA 28 /4,1933, 23-29.

Davies, N. De, G. \& GardineR, A.: Seven Private Tombs at Kurnah, London (The Egypt Exploration Society) 1948.

Davies N. De, G., GARDINER, A. \&, DAvies Nina De G.: The tomb of Antefoker, Vizier of Sésostris I and of his wife Senet. The Theban Tombs Series, second Memoir, EES, London, 1920

Dimitri, L.: « Portrait Versus Ideal Image », UCLA Encyclopedia of Egyptology 1/1, 2010, 1-14.

Dodson, A. M., \& IKRAM, S.: The Tomb in Ancient Egypt: Royal and Private Sepulchers from the Early Dynastic Period to the Romans, London (Thames \& Hudson) 2008.

Duell, P.: «The Mastaba of Mereruka, Part II: Chamber A 11-13, Doorjambs and Inscriptions of Chambers A 1-21, Tomb Chamber, and Exterior», OIP 39, 1938, PL.168

Dunham, D. \& SiMPSON, W.K.: Giza Mastabas, vol.1. The Mastaba of Queen Mersyankh III G 7530-7540, Boston (Museum of Fine Arts) 1974.

ERMAN, A. \& GRAPOW, H. (Eds.): Wörterbuch der ägyptischen Sprache I-V, Leipzig (J. Hinrichs) 1926-1931= $[W b$.$] .$ 
Evans, L.: «Animals in the Domestic Environment», In: Egyptian art.: Principles and Themes in Wall Scenes, Seies 6, Edited by L. DONOvan \& K. MCCORQUOdale (EDS.), 73-82, (Giza, Foreign Cultural Information Department) 2000.

EvANS, L.: Animal Behavior in Egyptian Art, Oxford (Aris \& Phillips) 2010.

EVANS, L. \& Woods, A.: «Further Evidence that Niankhnum and Khnumhotep were Twins», JEA 102, 2016, 55-72.

FAULKNER, R.O.: Concise Dictionary of Middle Egyptian, Oxford (Griffith Institute) 1962.

GARDINER, A.H.: Egyptian Grammar, Being an Introduction to the Study of Hieroglyphs, $3^{\text {rd }}$ revised ed., Oxford EvANS, 1957.

George, F., Marcelle, B. \& Etienne, D.: «Tombes thébaines Nécropole de Dirâ Abû' N-Naga Le tombeau de Rö̈», MIFAO 57/1, 1928.

Germond, P. \& Jaceues L.: An Egyptian Bestiary: Animals in Life and Religion in the Land of the Pharaohs, New York (Thames \& Hudson) 2001.

HAGSETH, M.: «Nilotic Livestock Transport in Ancient Egypt», Master of Arts Thesis, Texas A \& M University, (Megan Christine Hagseth) 2015.

Hartley, M., LorD, C. \& Evans. L.: «Animals in Ancient Egypt: Roles in life and death» in Death Is Only the Beginning: Egyptian Funerary Customs at the Macquarie Museum of Ancient Cultures. Edited by YANN TRISTANT \& ElLEN M. RYAN, Oxford (Aris \& Phillips) 2017.

HARTWIG, M.: The Tomb of Menna, in Valley of the Kings, (Kent Weeks ed.), White Star, Cairo (AUC press) 2013.

HARTWIG, M.: «Tomb Painting and Identity in Ancient Thebes 1419-1372 BCE», MONAEG 9, Turnhout (Brepols Publishers) 2004, 1-5.

Hodel-Hoenes, S.: Life and Death in Ancient Egypt, Scenes from Private Tombs in New Kingdom Thebes, New York (Cornell University Press) 2000.

Houlihan, P.F.: Animal World of the Pharaohs, London (Thames \& Hudson) 1996.

IKRAM, S.: Choice Cuts: Meat Production in Ancient Egypt, Leuven (Peeters Publishers) 1995.

IKRAM, S, ed.: Divine Creatures: Animal Mummies in Ancient Egypt, Cairo (AUC Press) 2005.

JonCKHEERE, D \& GILBERT, P.: «Le Bossu des Musées Royaux d'Art et d'Histoire de Bruxelles, avec une note de Pierre Gilbert, La date de la figurine de bossu», CdE 45/90, 1948, 24-35.

WEEKS, K.: «The Anatomical Knowledge of the Ancient Egyptians and the Representation of the Human Figure in Egyptian Art », Unpublished PhDThesis, Yale University, New Haven, 1970.

KanaWATI, N.: The Rock Tombs of El-Hawawish, The Cemetery of Akhmim, vol.1, Sydney (Macquarie Ancient History Association) 1980.

KanaWati, N.: The Teti Cemetery at Saqqara V. The Tomb of Hesi, Warminster, 1999.

KAnaWATI, N. \& ABDER-RAZIQ, M.: The Unis Cemetery at Saqqara 2: The Tomb of Iynefert and Ihy (reused by Idut), Oxford (Aris \& Phillips) 2003.

KAnAWATI, N.: Mereruka and his Family, part. 2: The Tomb of Waatetkhethor, ACE Reports 26, Oxford (Aris \& Phillips) 2008.

Kanawati, N. \& Evans, L.: The Cemetery of Meir, vol.4: The Tombs of Senbi 1 and Wekhhotep 1, ACE Reports 41, (Australian Centre for Egyptology) 2018.

KanaWATI, N. \& WoOdS, A.: Artists in the Old Kingdom: Techniques and Achievements, Cairo (Supreme Council of Antiquity) 2009.

Kanawati, N.: Beni Hassan: Artists in the Old Kingdom. Techniques and Achievements, Cairo (Supreme Council of Antiquity) 2009.

LESKO, L.: A dictionary of late Egyptian, V.I, Providence (RI: B.C. Scribe Publications) 1982. 


\section{Naglaa Fathy Shehab}

MAHRAN, H. \& KAMAL S.M.: «Physical Disability in Old Kingdom Wall Scenes», Athens Journal of History 2 /3, 2016, 169-191.

MALAISE, M. \& WiNAND, J.: Grammaire raisonnée de l'égyptien classique, Liège (AegLeod 6) 1999.

MeKHITARIAN, A.: «La tombe de Nebamon et Ipouky (TT181)», in R. TEFNIN (ed.): La peinture égyptienne. Un monde de signes à préserver. Actes du Colloque international de Bruxelles, avril 1994. (Monumenta AEgyptiaca, VII = Serie Imago, 1), 21-28, Bruxelles (Fondation Egyptologique Reine Elisabeth) 1997.

MONTET, P.: Everyday Life in Egypt in the Days of Rameses the Great, translated by MAXWELL-HysLoP, A. \& Drower, M., Philadelphia (Philadelphia: University of Pennsylvania Press) 1981.

Motтe, A.: «Reden und Rufe, a Neglected Genre? Towards a Definition of the Speech Captions in Private Tombs», BIFAO 117, 2017, 307-308.

Moussa, A.M \& Altenmüller, H.: Das Grab des Nianchchnum und Chnumhotep, Old Kingdom Tombs at the Causeway of King Unas at Saqqara. Archäologisches Veröffentlichungen 21, Mainz am Rhein (Philipp von Zabern) 1977.

NAVILLE, E.: The XI ${ }^{\text {th }}$ Dynasty Temple at Deir El Bahari III, London (Boston, Mass, the Egypt Exploration Fund) 1913.

O'NeILl, Megan C.: «The Decorative Program of the Eighteenth-Dynasty Tomb of Pairy (TT 139)» Master of Arts (MA), Georgia State University, 2015.

OSER, A. P.: «Nefer and Kahay», Master of Arts in Egyptology, Macquarie University, 2011.

PAGET, R.F.E. \& PIRIE, A.A.: The Tomb of Ptah-hetep, in Buibell, J.E., The Ramesseum, London (B. Quaritch) 1896.

PECK, W.: The Material World of Ancient Egypt, New York (Cambridge University Press) 2013.

PORCIER, S., IKRAM, S. \& PASQUALI, S., (EDS.): «Creatures of Earth, Water and Sky»: Essays on Animals in Ancient Egypt and Nubia, Leiden (Sidestone Press) 2019.

PORTER, B. \& MOSS, R.: Topographical bibliography of ancient Egyptian hieroglyphic texts, reliefs, and paintings, vol.1, the Theban necropolis, part 1. Private tombs, Oxford (Griffith institute Ashmolean museum) $1960=[P M$.$] .$

PORTER, B. \& MOSS, R.: Topographical Bibliography of Ancient Egyptian Hieroglyphic Texts, Reliefs and Paintings, vol.3, part 2, Memphis: Saqqâra to Dahshûr, Oxford (Griffith institute) 1981= [PM.].

ROBINS, G.: «Hair and the Construction of Identity in Ancient Egypt c. 1480-1350 BCE», JARCE 36, 1999, 55-69.

Romano, J.: Daily Life of the Ancient Egyptians, Pittsburgh (The Carnegie Museum of Natural History) 1990.

RотH, A.M.: A Cemetery of Palace Attendants: Including G 2048-2099, G 2230+2231, and G 2240, Giza Mastabas VI, Boston (Museum of Fine Arts) 1995.

SIMPSON, W. K.: Mastabas of the Western Cemetery, Part 1: Sekhemka (G 1029); Tjetu I (G 2001); Iasen (G 2196); Penmeru (G 2197); Hagy, Nefertjentet, and Herunefer (G 2352/53); Djaty, Tjetu II, and Nimesti (G 2337X, 2343, 2366), Guiza Mastabas 4, Boston (Museum of Fine Arts) 1980.

SMITH,W. St.: A History of Egyptian sculpture and Painting in the Old Kingdom, London (Oxford University Press) 1949.

SteINDORFF, G.: Das grab des Ti, Leipzig (Hinrichs'sche Buchhandlung) 1913.

TASSIE, G. J.: «The Social and Ritual Contextualization of Ancient Egyptian Hair and Hairstyles from the Protodynastic to the end of the Old Kingdom », PhD Thesis, Institute of Archaeology University College, London, 2008. 
TASSIE, G. J.: «Hairstyles Represented on the Salakhana Stelae»: T. du QUESNE (ED.) The Salakhana Trove: Votive Stelae and Other Objects from Asyut, London (Oxfordshire Publications in Egyptology 7) 2009, 459-536.

TASSIE, G. J.: «What Your Hair Says About You: Changes in Hairstyles as An Indicator of State Formation Progresses», in: R.F. FRIEDMAN \& P.N. FISKE (EDS.): Egypt at its Origins 3: proceedings of the third international conference «Origin of the state: Predynastic and early dynastic Egypt», Leuven (Orientalia Lovaniensia Analecta 205) 2011, 605-643.

TYLOR J.J. \& GRIFFITH, F.L.: The tomb of Paheri at El kab, Wall drawings and monuments of El-Kab, , London (The Egypt Exploration Fund) 1894.

VANDIER, J.: Manuel d'Archéologie Égyptienne: Tome V Bas-Reliefs et Peintures Scénes de la vie Quotidienne, vol. 5, Paris (Centre National de la Recherche Scientifique) 1969.

Verma, S.: Cultural Expression in the Old Kingdom Elite Tomb, Oxford (Archaeopress) 2014.

VERNUS, P.: «Les inscriptions de Sa-Mout surnommé Kyky», Revue d'égyptologie 30, 1978, 115-146.

: «Comment l'élite se donne à voir dans le programme décoratif de ses chapelles funéraires. Stratégie d'épure, stratégie d'appogiature et le frémissement du littéraire», CRIPEL 28, 2010, 67-115.

SCHEIL, V.: « Le tombeau de Pâri», Mem. Miss 5/ 2, 581-590.

WALSEM, V.: «Iconography of Old Kingdom Elite Tombs: Analysis and Interpretation, Theoretical and Methodological Aspects», Mémoire de la Société d'Études Orientales 35, 2005, Leiden (Peeters), 45.

WEEKS, K.R.: Mastabas of Cemetery G 6000 (including G 6010 (Neferbauptah); G6020 (Iymery); G6030 (Ity);G6040 (Shepseskafankh), Giza Mastabas V, Boston (Museum of Fine Arts) 1994.

WILD, H.: «Le Tombeau de Ti», La Chapelle (Part 1), MIFAO 65/2, 1953, PL.LXXX B, PL.LXXXI \& CXIV.

WILD, H.: «L'adresse aux visiteurs du tombeau de Ti», BIFAO 58, 1959, 101-113.

Wood, A.: «žšš w3 $\underline{d}$ Scenes of the Old Kingdom Revisited», In Nigel AND HelEn STRUDWick (EDS.): Old Kingdom, New Perspectives: Egyptian Art and Archaeology, 2750-2150 BC, Oxford (Oxbow Books) 2011, 314-319.

WoOds, A. \& LEARY, N.: " 'Art', Aesthetics and the Functioning Image in Ancient Egyptian Elite Tombs», In Death is Only the Beginning: Egyptian Funerary Customs at the Museum of Ancient Cultures, Macquarie University, Edited by YANN TRISTANT \& ElLEN M. RYAN, Oxford (Aris and Phillips) 2017, 77.

WRESZINSKI, W.: Atlas zur altägyptischen Kulturgeschichte I, of Atlas zur altaegyptischen Kulturgeschichte, Leipzig (J.C. Hinrichs Verlag) 1923.

WrESZINSKI, W.: Atlas zur altägyptischen Kulturgeschichte III: Gräber des Alten Reiches, Leipzig (Hinrich) 1936.

Yvonne, H.M. \& PaOlo, S.J.: «The Chapel of Kagemni»: Scene Details-Egypt in Miniature, vol.1, (Series Editor: Geoffrey T. Martin), Oxford (Oxford Expedition to Egypt) 2006.

ZIEGLER, CHR.: Catalogue des stèles, peintures et reliefs égyptiens de l'Ancien Empire et de la première période intermédiaire. Paris (Réunion des musées nationaux) 1990. 